\title{
Penerapan metode Promethee dalam evaluasi kinerja penyuluh pertanian pada Unit Pelaksana Teknis Balai Penyuluh Pertanian
}

\author{
Dewi Suranti \\ Teknik Informatika, Universitas Dehasen Bengkulu, Bengkulu, Indonesia
}

email:dewisuranti@unived.ac.id

\begin{tabular}{l}
\hline I N F O A R T I K E L \\
\hline Sejarah artikel: \\
Menerima 14 Agustus 2018 \\
Revisi 16 April 2019 \\
Diterima 17 April 2019 \\
Online 10 Mei 2019 \\
\hline Kata kunci: \\
entering flow \\
evaluasi kinerja \\
net flow \\
penyuluh pertanian \\
Promethee \\
\hline
\end{tabular}

Keywords: agricultural extensionist entering flow net flow performance evaluation Promethee

Style APA dalam menyitasi artikel ini:

Suranti, D. (2019).

Penerapan metode Promethee dalam evaluasi kinerja penyuluh pertanian pada Unit Pelaksana Teknis Balai Penyuluh Pertanian. Register: Jurnal Ilmiah Teknologi Sistem Informasi, 5(1), 13-23.

\begin{abstract}
ABSTRAK
Unit Pelaksana Teknis Balai Penyuluhan Pertanian (UPT BPP) Sukaraja berupaya untuk meningkatkan kinerja penyuluh pertanian guna meningkatkan kualitas penyuluh, sebab kinerja yang negatif akan membawa perubahan tidak baik terhadap peningkatan hasil pertanian di wilayah binaan UPT BPP Sukaraja. Evaluasi kinerja penyuluh di UPT BPP Sukaraja dilaksanakan setiap tiga bulan dan enam bulan sekali. Selama ini, evaluasi dilakukan secara manual, sehingga kegiatan evaluasi tidak dapat dilaksanakan dengan tepat waktu karena terkendala tenaga kerja yang tidak memadai. Model yang digunakan dalam kajian evaluasi kinerja penyuluh pertanian ini menggunakan motede Promethee (Preference Ranking Organizational Method for Enrichment Evaluation). Metode Promethee dilakukan pertama kali dengan menentukan bobot kualitatif alternatif dari setiap kriteria, menentukan tipe fungsi preferensi, menghitung nilai preferensi antar alternatif, menghitung index preferensi, kemudian menghitung nilai leaving flow, entering flow, dan net flow. Hasil penerapan metode ini menghasilkan komposisi rangking atau peringkat penyuluh pertanian yang baik, yaitu penyuluh dengan inisial Sd dengan nilai net flow 1,31106 dan yang membutuhkan pembinaan adalah penyuluh dengan inisial Sj dan Dm dengan nilai net flow $-0,81665$ dan $-0,51111$.
\end{abstract}

\begin{tabular}{l} 
ABSTRACT \\
\hline Technical Implementation Unit of the Agricultural Extension Center (UPT BPP) \\
Sukaraja supports to improve the performance of extension agents in order to improve the \\
quality of extension agents, because negative performance will bring changes in bad \\
changes to the increase in agricultural yields in the target areas of UPT BPP Sukaraja. \\
The performance evaluation of instructors at UPT BPP Sukaraja is conducted every three \\
months and every six months. So far, evaluations have been carried out manually, so that \\
evaluation activities cannot be carried out in a timely manner because of constraints on \\
inadequate labor. In order to evaluate instructor's performance, a model namely Promethe \\
(Preference Ranking Organizational Method for Enrichment Evaluation) was used. It was \\
started with identifying certain alternatives and types of preferences function, followed by \\
determining preferences value between alternatives. Afterwards, preferences index, \\
leaving and entering value, and net flows should be calculated. The method produces good \\
ranks of agricultural instructors, with initials Sd and a net flow value of 1.31106 . \\
Furthermore, it produces extension agents on initials Sj and Dm with Net flow values of \\
-0.81665 and -0.51111. \\
() 2019 Register: Jurnal IImiah Teknologi Sistem Informasi. Semua hak cipta dilindungi undang-undang.
\end{tabular}

(c) 2019 Register: Jurnal IImiah Teknologi Sistem Informasi. Semua hak cipta dilindungi undang-undang.

\section{Pendahuluan}

Kinerja penyuluh pertanian adalah tanggapan atau hasil yang dicapai individu secara aktual pada suatu instansi dalam melaksanakan tugas penyuluhan dan pembinaan. Hal ini menjadi tanggung jawab yang dipercayakan kepadanya agar dapat dilaksanakan dengan baik sesuai dengan batasan waktu 
tertentu untuk mewujudkan tujuan utama organisasi tersebut (Hutahaean, Rosnita, \& Yulida, 2016). Perbaikan kinerja petani berdampak pada peningkatan produksi petani yang dapat dicapai jika kinerja penyuluh terarah dalam pemecahan dan penyelesaian permasalahan yang dihadapi petani, baik masalah teknis maupun nonteknis, dalam usaha tani (Bahua, 2010).

Penilaian kinerja yang baik adalah harapan semua pemangku kepentingan pada suatu instansi, termasuk instansi pertanian. Terkait penilaian kinerja seorang penyuluh dapat dilihat dari awal kegiatan yang dilakukan, mulai dari persiapan, pelaksanaan, evaluasi, dan pelaporan. Adapun komponen pendukung lainnya yang menunjang keberhasilan seorang penyuluh terlihat dari aspek penilaian kepemimpinan, komunikasi, serta penguasaan teknis. Aspek penilaian tersebut merupakan rangkaian kerja yang tidak dapat dipisahkan dari program kerja seorang penyuluh didasarkan pada analisis kebutuhan petani yang mencerminkan sasaran keberhasilan yang ingin dicapai (Sapar \& Butami, 2017). Penilaian kinerja secara umum merupakan upaya suatu instansi dalam melakukan pengukuran serta evaluasi kinerja karyawan dalam menyelesaikan tugas dan beban kerja yang menjadi tanggung jawabnya, dengan harapan ada peningkatan kualitas kinerja karyawan (Sari \& Saleh, 2014).

Menurut informasi koordinator penyuluh, Unit Pelaksana Teknis Balai Penyuluh Pertanian (UPT BPP) Sukaraja memiliki 20 orang penyuluh yang membina 22 desa/kelurahan dengan jumlah 88 kelompok tani binaan. Dijelaskan dalam UU No. 16 Tahun 2006, bahwa satu tenaga penyuluh hanya dapat membina satu desa. Namun kenyataannya, di lapangan masih ditemukan penyuluh pertanian yang mendapatkan tugas membina beberapa desa. Artinya, seorang penyuluh membina lebih dari satu desa. Hal ini menyebabkan belum terlihatnya peningkatan yang signifikan pada kemandirian dan keberdayaan petani. Tujuan penelitian ini adalah untuk mengetahui kinerja penyuluh, sehingga diharapkan tidak ditemukan lagi penyuluh pertanian yang membina lebih dari 1 (satu) desa. Selain itu, penelitian ini juga bertujuan terwujudnya penyuluh yang berwawasan di wilayah binaan UPT BPP Sukaraja.

Penelitian ini menerapkan pengembangan sistem model Waterfall. Tahapannya dimulai dari pengumpulan data, analisis, hingga implementasi dan pengujian sistem. Decision support akan mempermudah evaluasi kinerja penyuluh di wilayah UPT BPP Sukaraja ini dengan kajian Promethee (Preference Ranking Organizational Method for Enrichment Evaluation), yaitu model multikriteria dengan menentukan prioritas dalam penyelesaian masalah (Apriliani \& Somantri, 2019). Metode Promethee sering dikenal dengan metode outranking, yaitu setiap kriteria terpisah dalam pasangan perbandingan kebijaksanaan alternatif (Vinodh \& Girubha, 2012) dan metodologi peringkat alternatif (Yu, Xu, \& YingMa, 2013). Pada berbagai metode Multiple Criteria Decision Making (MCDM), perkembangan outranking memiliki fleksibilitas yang pesat sehingga dapat mengambil keputusan pada situasi yang nyata. Tujuannya adalah tersedianya pengelolahan informasi, sehingga dapat membantu dalam pengambilan keputusan dengan memilih berbagai alternatif terbaik.

Kajian terdahulu yang menjadi patokan dalam melakukan penelitian ini di antaranya adalah: 1) penelitian Adawiyah (2015) tentang penentuan dosen baik di STMIK Bumigora dengan kriteria yang digunakan yaitu kriteria penelitian, pengajaran, pengabdian, dan kedisiplinan. Namun, hasil perhitungan yang diperoleh belum terlihat jelas; 2) penelitian Wibowo, Permanasari, dan Hidayah (2015) yang bertujuan untuk mengatasi permasalahan pihak manajemen yang mengalami kesulitan dalam melakukan penilaian secara tepat, terkait marketing officer di Bank Rakyat Indonesia (BRI) yang berjumlah cukup banyak. Adanya penelitian ini mempermudah pengambilan keputusan dapat berjalan dengan cepat dan akurat; 3) penelitian Ariansyah, Aknuranda, dan Rachmadi (2013) guna mengevaluasi hasil pemantauan penyidik yang dilakukan dengan kurang efektif dan kurang cermat, karena hanya menjumlahkan nilai kriteria yang ada dan mengesampingkan kualitas kriteria penilaian itu. Melalui menerapkan Promethee, kinerja penyidik dapat dievaluasi dengan memberikan pemeringkatan kinerja penyidik dengan mempertimbangkan bobot dari setiap kriteria yang ada dan penelitian ini menghasilkan solusi yang dapat digunakan dalam proses evaluasi kinerja penyidik.

Perbedaan penelitian ini dengan yang sebelumnya adalah penelitian ini ditekankan pada penerapan metode dengan menjelaskan secara detail langkah-langkah perhitungan metode Promethee, serta membandingkan hasil penerapan metode sebelumnya dengan menggunakan metode Promethee menggunakan kriteria yang sama (Suranti \& Sari, 2018). Nantinya akan dikembangkan suatu sistem penentuan kinerja penyuluh pertanian di UPT BPP Sukaraja dengan menggunakan metode Promethee. 
Di dalamnya terdapat enam tahapan yaitu menentukan bobot kualitatif alternatif, menentukan jenis fungsi preferensi, menghitung hasil preferensi, menghitung index preferensi, menghitung nilai, serta memeringkatkan nilai tersebut.

\section{Metode Penelitian}

Metode penelitian dalam membangun sistem diilustrasikan berupa diagram alir atau flowchart. Diagram alir penelitian dalam evaluasi kinerja penyuluh pertanian dengan menggunakan metode Promethee ditunjukkan pada Gambar 1.

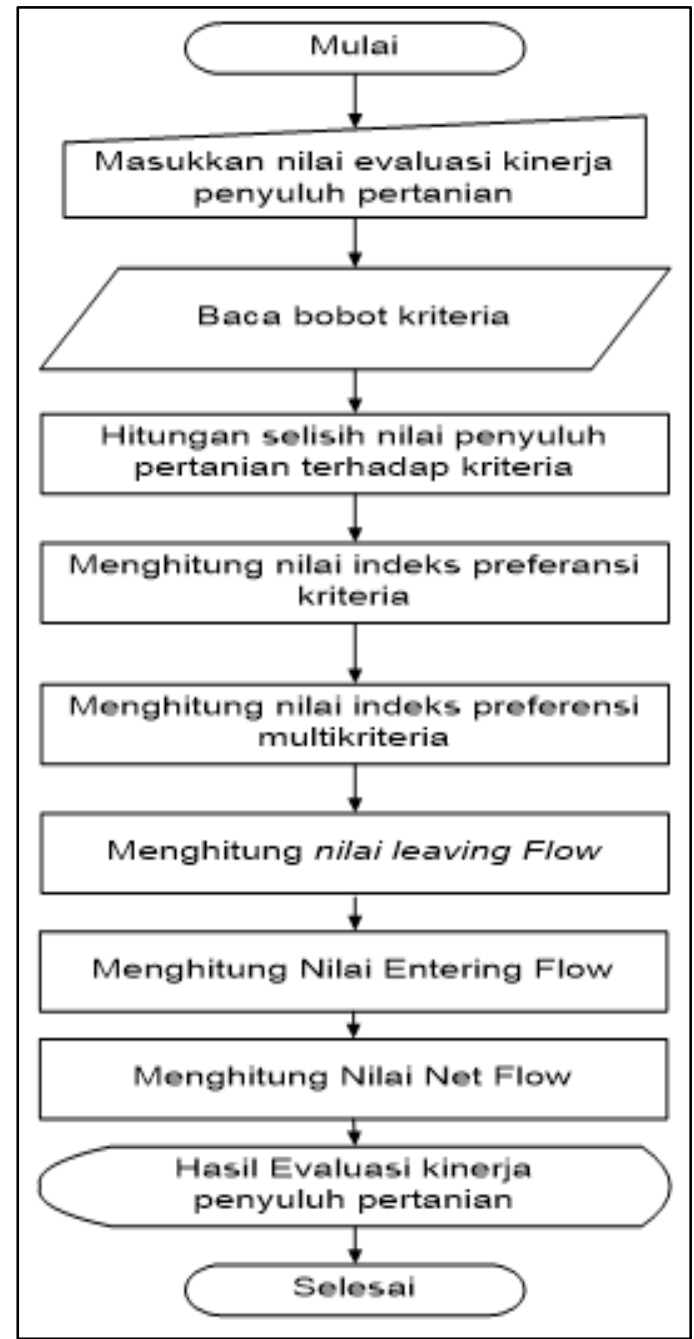

Gambar 1. Flowchart pemeringkatan evaluasi kinerja penyuluh pertanian dengan metode Promethee

Langkah-langkah dalam evaluasi kinerja penyuluh pertanian sesuai dengan flowchart adalah memasukkan nilai evaluasi yang diperoleh dari fomulir yang telah diisi oleh tim evaluasi UPT BPP berdasarkan nilai bobot yang diberikan, menghitung selisih nilai penyuluh terhadap kriteria, nilai indeks, nilai leaving flow, nilai entering flow, dan nilai net flow. Hasil nilai net flow bisa dilihat dari evaluasi kinerja dengan pemeringkatan hasil evaluasi kinerja penyuluh pertanian melalui penetapan prioritas.

Menetapan prioritas alternatif yang telah ada diperoleh dari prinsip yang didasarkan pada $(\forall i \mid f i(.) \rightarrow \mathfrak{R}$ real world], yakni $K$ merupakan kumpulan dari alternatif, $f i(i=1,2, \ldots, K)$ adalah nilai relatif kriteria dari setiap alternatif. Dalam penerapannya, untuk menerangkan sejumlah kriteria yang ditetapkan adalah $K$ yang merupakan penilaian dari $\mathfrak{R}[$ real world]. Nilai $f$ merupakan alternatif yang dipertimbangkan untuk mendapat nilai kriteria yang lebih baik, yang berlaku pada semua kriteria dan alternatif yang akan terpilih dari nilai preferansi diperoleh dari akumulasi nilai tersebut. Diagram alur metode Promethee dapat dilihat pada Gambar 2.

Untuk semua kriteria, suatu alternatif akan dipertimbangkan memiliki nilai kriteria yang lebih baik ditentukan oleh nilai $f$. Akumulasi dari nilai ini menentukan nilai preferensi atas masing-masing alternatif yang akan dipilih. Diagram alur metode Promethee dapat dilihat pada Gambar 2.

Tahapan dalam menyelesaian metode Promethee adalah sebagai berikut (Herman, 2014). 


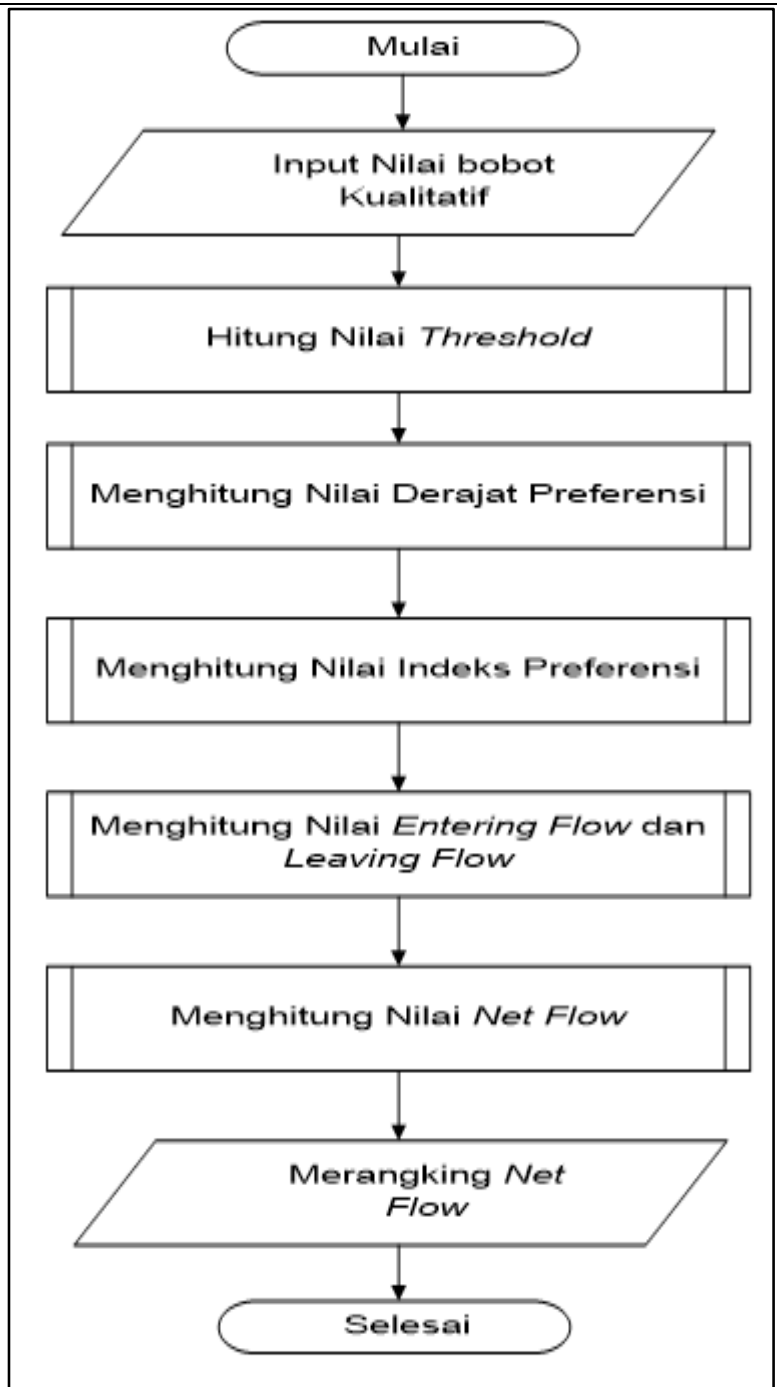

Gambar 2. Flowchart metode Promethee

1. Menentuan nilai atau bobot kualitatif alternatif dari kriteria.

Prosedur optimasi yang merupakan nilai nyata dari suatu kriteria dan tujuan adalah nilai $f$. $a \in$ $K, f(a)$ pada setiap alternatif adalah evaluasi untuk suatu kriteria. Pada waktu akan dibandingkan, $a_{1}, a_{2} \in K$, terlebih ditentukan preferansi perbandingannya. Penyampaian intensitas $(P)$ dari preferensi alternatif $a_{1}$ terhadap alternatif $a_{2}$ (Brans \& Mareschal, 2016) sehingga

a. $P\left(a_{1}, a_{2}\right)=0$, berarti tidak ada beda antara $a_{1}$ dan $a_{2}$, atau tidak ada preferensi dari $a_{1}$ lebih baik dari $a_{2}$

b. $P\left(a_{1}, a_{2}\right) \sim 0$, berarti lemah, preferensi dari $a_{1}$ lebih baik dari $a_{2}$

c. $P\left(a_{1}, a_{2}\right) \sim 1$, berarti kuat, preferensi dari $a_{1}$ lebih baik dari $a_{2}$.

d. $P\left(a_{1}, a_{2}\right)=1$, berarti mutlak, preferensi dari $a_{1}$ lebih baik dari $a_{2}$.

2. Menentukan tipe fungsi preferensi dan nilai threshold.

$P\left(a_{1}, a_{2}\right)=P\left\{f\left(a_{1}\right)-f\left(a_{2}\right)\right\}$ perhitungan fungsi preferensi menperoleh hasil yang berbeda antardua evaluasi.

3. Menghitung nilai preferensi antaralternatif dengan cara membandingkan suatu alternatif dengan alternatif lain.

Bentuk fungsi preferensi dari kriteria ada 6, yaitu sebagai berikut (Gunawan \& Astuti, 2013).

a. Biasa (Usual criterion) 


$$
H(d)=\left\{\begin{array}{lll}
0 & \text { jika } & d \leq 0 \\
1 & \text { jika } & d>0
\end{array}\right.
$$

Pada Persamaan $1, H(d)$ adalah fungsi selisih kriteria antaralternatif dan $d$ adalah selisih nilai kriteria $d=f(a)-f(b)$. Pada kasus ini, tidak ada beda (sama penting) antara $a$ dan $b$ jika dan hanya jika $f(a)=f(b)$, apabila kriteria pada masing-masing alternatif memiliki nilai berbeda, pembuat keputusan membuat preferensi mutlak untuk alternatif memiliki nilai yang lebih baik.

b. Quasi (Quasi criterion)

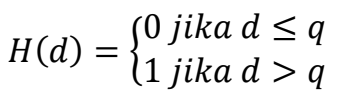

Pada Persamaan 2, $H(d)$ adalah fungsi selisih kriteria antaralternatif, $d$ adalah selisih nilai kriteria $d=f(a)-f(b)$, dan $q$ harus merupakan nilai tetap. Pada kasus ini, nilai $H(d)$ dari masing-masing alternatif untuk kriteria tertentu tidak melebihi nilai $q$. Jika melebihi nilai $q$ untuk selisih hasil evaluasi masing-masing alternatif, akan terjadi bentuk preferensi mutlak. Untuk penggunaan kriteria kuasi, terlebih dahulu tentukan nilai $q$. Nilai ini dapat menjelaskan pengaruh yang signifikan dari suatu kriteria.

c. Preferensi linier

$$
H(d)=\left\{\begin{array}{c}
0 \text { jikad } \leq 0 \\
\frac{d}{q} j i k a 0 \leq d \leq q \\
1 \text { jikad }>q
\end{array}\right.
$$

Pada Persamaan 3, $H(d)$ adalah nilai selisih kriteria antaralternatif, $d$ adalah selisih dari nilai kriteria $d=f(a)-f(b)$, dan $p$ adalah nilai kecenderungan atas. Dalam kriteria ini dapat dilihat sebuat kejelasan, nilai $p$ memiliki selisih nilai yang rendah, nilai $d$ memiliki peningkatan secara linier preferensi dari pembuat keputusan. Jika nilai $d$ mendapatkan nilai lebih tinggi dibandingkan dengan nilai $p$, terjadi bentuk preferensi mutlak. Untuk mengambil keputusan, terlebih dahulu mengindentifikasi beberapa kriteria nilai dari kecenderungan atas (nilai $p$ ).

d. Level (Level criterion)

$$
H(d)=\left\{\begin{array}{c}
0 \text { jikad } \leq q \\
0,5 \text { jikaq } \leq d \leq p \\
1 \text { jikad }>p
\end{array}\right.
$$

Pada Persamaan $4, H(d)$ adalah fungsi selisih kriteria antaralternatif, $d$ adalah selisih nilai kriteria $d=f(a)-f(b), p$ adalah nilai kecenderungan atas, dan $q$ harus merupakan nilai tetap. Dalam kondisi seperti ini, kecenderungan tidak berbeda $q$ dan kecenderungan prefensi $p$ ditentukan secara simultan. Jika $d$ berada di antara nilai $q$ dan $p$, hal ini berarti situasi preferensi lemah $H(d)=0,5$.

e. Preferensi linier dan area yang tidak berbeda

$$
H(d)=\left\{\begin{array}{c}
0 \text { jikad } \leq q \\
\frac{d-q}{p-q} j i k a q \leq d \leq p \\
1 \text { jikad }>p
\end{array}\right.
$$

Pada Persamaan 5, $H(d)$ adalah fungsi selisih kriteria antaralternatif, $d$ adalah selisih nilai kriteria $d=f(a)-f(b), p$ adalah nilai kecenderungan atas, dan $q$ harus merupakan nilai tetap. Pada kondisi seperti ini, pengambil keputusan mempertimbangkan peningkatan preferensi secara linier dari tidak berbeda hingga preferensi mutlak dalam area antara dua kecenderungan $q$ dan $p$.

f. Gaussian (Gaussian criterion)

$$
H(d)=\left\{\begin{array}{c}
0 \text { jikad } \leq 0 \\
1-e-\frac{d^{2}}{z a^{2}} \text { jikad }>0
\end{array}\right.
$$


Pada Persamaan $6, H(d)$ adalah fungsi selisih kriteria antar alternatif dan $d$ adalah selisih nilai kriteria $d=f(a)-f(b)$.

4. Indeks multikriteria

Ditentukan berdasarkan nilai rata-rata bobot dari fungsi preferensi Pi.

$\Phi(a, b)=\sum_{i=0}^{n} \pi_{i} p_{i}(a, b): \forall a, b \in A$

$\Phi(a, b)$ yang merupakan intensitas preferensi pembuat keputusan yang menyatakan bahwa alternatif $a$ lebih baik dari alternatif $b$ dengan pertimbangan secara simultan dari seluruh kriteria. Hal ini dapat disajikan dengan nilai antara nilai 0 dan 1, dengan ketentuan sebagai berikut.

a. $\Phi(a, b)=0$ menunjukan preferensi lemah alternatif $a>b$ untuk semua kriteria.

b. $\Phi(a, b)=1$ menunjukan preferensi yang kuat untuk alternatif $a>b$.

Indeks preferensi ditentukan dari nilai outrangking pada kriteria dari masing-masing alternatif. Ini disajikan sebagai grafik nilai outrangking, beberapa node merupakan alternatif penilaian kriteria tertentu.

5. Menghitung dan merangking nilai leaving flow $\left(\Phi^{+}\right)$, entering flow $\left(\Phi^{-}\right)$, dan net flow

Perhitungan arah preferensi dipertimbangkan berdasarkan nilai indeks. Pemeringkatan dalam metode Promethee terdiri atas (Zuraidah \& Marlinda, 2018)

a. Leaving flow seperti disajikan pada Persamaan 8.

$$
\Phi(a)=\frac{1}{n-1} \sum_{x \in \mathrm{A}} \Phi(a, x)
$$

b. Entering flow disajikan pada Persamaan 9 .

$\Phi^{-}(a)=\frac{1}{n-1} \sum_{x \in \mathrm{A}} \Phi(a, x)$

c. Net flow dengan seperti disajikan pada Persamaan 10.

$\Phi(a)=\Phi^{+}(a)-\Phi^{-}(a)$

Di sini, $\Phi(a, x)$ menunjukan preferensi, bahwa alternatif $a$ lebih baik dari alternatif $x, \Phi(x, a)$ menunjukan preferensi bahwa alternatif $x$ lebih baik dari alternatif $\left.a, \Phi^{+}(a)\right)$ adalah leaving flow yang digunakan untuk menentukan urutan prioritas pada proses Promethee yang menggunakan urutan parsial. $\Phi^{-}(a)$ adalah entering flow yang digunakan untuk menentukan urutan prioritas pada proses Promethee yang menggunakan urutan parsial, $\Phi^{+}(a)$ dan net flow yang digunakan untuk menghasilkan keputusan akhir penentuan urutan dalam menyelesaikan masalah sehingga menghasilkan urutan lengkap.

\section{Hasil dan Pembahasan}

Kriteria dalam evaluasi kinerja dilakukan dengan cara menentukan beberapa komponen keberhasilan

Tabel 1. Kriteria Evaluasi Kinerja Penyuluh Pertanian (Pertanian, 2013)

\begin{tabular}{|c|c|}
\hline Simbol Kriterian & Kriteria \\
\hline $\mathrm{Kr} \mathrm{I}$ & Membuat data potensi wilayah dan agro ekosistem \\
\hline $\mathrm{Kr}_{2}$ & Memberikan bimbingan Penyusunan Rencana Definitif Kebutuhan Kelompok RDKK \\
\hline $\mathrm{Kr}_{3}$ & Menyusun program penyuluhan pertanian \\
\hline $\mathrm{Kr}_{4}$ & Membuat rencana kerja tahunan penyuluh pertanian (RKTPP) \\
\hline $\mathrm{Kr}_{5}$ & Melaksanakan diseminasi/penyebaran materi penyuluhan \\
\hline $\mathrm{Kr}_{6}$ & Melaksanakan penerapan metode penyuluhan pertanian dalam bentuk kunjungan \\
\hline $\mathrm{Kr} 7$ & Melaksanakan penerapan metode penyuluhan dalam bentuk demonstrasi \\
\hline $\mathrm{Kr} 8$ & Melaksanakan penerapan metode penyuluhan dalam bentuk temu-temu \\
\hline $\mathrm{Kr} 9$ & Melaksanakan penerapan metode penyuluhan dalam bentuk kursus \\
\hline $\mathrm{Kr}_{10}$ & Melakukan peningkatan kapasitas petani terhadap akses informasi \\
\hline Krin & $\begin{array}{l}\text { Menumbuhkan kelompok tani/gabungan kelompoktani (gapoktan) dari aspek kualitas } \\
\text { dan kuantitas }\end{array}$ \\
\hline $\mathrm{Kr}_{12}$ & Meningkatkan kelas kelompok tani dari aspek kuantitas dan aspek kualitas \\
\hline $\mathrm{Kr}_{13}$ & Melakukan bimbingan teknis dalam meningkatkan produksi komoditi unggulan \\
\hline $\mathrm{Kr}_{14}$ & Melakukan evaluasi pelaksanaan penyuluh pertanian \\
\hline $\mathrm{Kr}_{15}$ & Melakukan evaluasi dampak penyuluhan pertanian \\
\hline $\mathrm{Kr}_{16}$ & Membuat laporan pelaksanaan penyuluhaan pertanian \\
\hline
\end{tabular}


penyuluh pertanian yang ditetapkan oleh Dinas Pertanian. Penerapan metode Promethee dalam evaluasi menggunakan 16 kriteria yang diajukan dalam pengambilan keputusan sesuai dengan Pertanian (2013), diperlihatkan pada Tabel 1. Untuk kriteria yang disajikan pada Tabel 1 dibuat tingkat kepentingannya ke dalam kategori bobot yang terlihat pada Tabel 2.

\begin{tabular}{|c|c|}
\hline Bobot & Nilai Bobot \\
\hline 5 & Sangat Baik \\
\hline 4 & Baik \\
\hline 3 & Cukup \\
\hline 2 & Jelek \\
\hline 1 & Sangat Jelek \\
\hline
\end{tabular}

Penelitian ini menggunakan 6 penyuluh pertanian sebagai sampel untuk dievaluasi kinerjanya berdasarkan kriteria Permentan 2013. Enam sampel penyuluh tersebut terlihat pada Tabel 3.

Tabel 3. Data penyuluh pertanian yang dievaluasi

\begin{tabular}{cl}
\hline Inisial & Nama Penyuluh \\
\hline Sy & Syahrial \\
$\mathrm{Sj}$ & Sirajuddin \\
$\mathrm{Sd}$ & Sudirman \\
$\mathrm{Es}$ & Eko Susanto \\
$\mathrm{Dm}$ & Deasy Mediana \\
$\mathrm{Ak}$ & Abukery \\
\hline
\end{tabular}

Tabel 4 merupakan data hasil evaluasi kinerja berdasarkan instrumen evaluasi kinerja penyuluh pertanian UPT BPP Sukaraja berdasarkan instrumen yang telah diisi oleh Tim Penilai Evaluasi Kinerja di UPT BPP Sukaraja.

\begin{tabular}{|c|c|c|c|c|c|c|c|}
\hline \multirow{2}{*}{ No. } & \multirow{2}{*}{ Kriteria } & \multicolumn{6}{|c|}{ Nilai Evaluasi Penyuluh } \\
\hline & & Sy & $S \mathbf{j}$ & Sd & Es & $\mathrm{Dm}$ & Ak \\
\hline 1 & $\mathrm{Kr}_{1}$ & 5 & 5 & 5 & 3 & 3 & 4 \\
\hline 2 & $\mathrm{Kr}_{2}$ & 4 & 3 & 5 & 4 & 2 & 3 \\
\hline 3 & $\mathrm{Kr}_{3}$ & 3 & 3 & 4 & 4 & 4 & 5 \\
\hline 4 & $\mathrm{Kr}_{4}$ & 4 & 3 & 3 & 4 & 2 & 3 \\
\hline 5 & $\mathrm{Kr}_{5}$ & 2 & 2 & 4 & 3 & 3 & 4 \\
\hline 6 & $\mathrm{Kr}_{6}$ & 3 & 3 & 3 & 4 & 2 & 5 \\
\hline 7 & $\mathrm{Kr}_{7}$ & 5 & 5 & 5 & 3 & 5 & 2 \\
\hline 8 & $\mathrm{Kr}_{8}$ & 5 & 5 & 5 & 5 & 5 & 3 \\
\hline 9 & $\mathrm{Kr} 9$ & 4 & 3 & 5 & 4 & 2 & 4 \\
\hline 10 & $\mathrm{Kr}_{10}$ & 3 & 3 & 4 & 4 & 4 & 3 \\
\hline 11 & $\mathrm{Kr}_{11}$ & 4 & 3 & 3 & 4 & 2 & 4 \\
\hline 12 & $\mathrm{Kr}_{12}$ & 2 & 2 & 4 & 3 & 3 & 5 \\
\hline 13 & $\mathrm{Kr}_{13}$ & 4 & 3 & 5 & 4 & 2 & 5 \\
\hline 14 & $\mathrm{Kr}_{14}$ & 3 & 3 & 4 & 4 & 4 & 3 \\
\hline 15 & $\mathrm{Kr}_{15}$ & 4 & 3 & 3 & 4 & 2 & 4 \\
\hline 16 & $\mathrm{Kr}_{16}$ & 2 & 2 & 4 & 3 & 3 & 4 \\
\hline \multicolumn{2}{|c|}{ Jumlah Nilai } & 57 & 51 & 66 & 60 & 48 & 61 \\
\hline
\end{tabular}

Tahap nilai preferensi dilakukan dengan cara membandingkan antarkriteria yakni mencari selisih nilai kriteria satu dengan kriteria lainnya. Selanjutnya, dilakukan penghitungan nilai preferensi dengan memilih jenis preferensi yang ada. Hasil perhitungan lengkap dapat dilihat pada Tabel 5. Salah satu nilai preferensi dan hasil perhitungan nilai preferensi secara lengkap untuk setiap kriteria dapat dilihat pada Tabel 6. Tahapan perhitungan Indeks Multikriteria dilakukan dengan cara berikut.

$$
\begin{aligned}
& (\mathrm{Sy}, \mathrm{Sj})=\frac{1}{6}(0+1+0+1+0+0+0+0+1+0+1+0+1+0+1+0)=\frac{6}{6}=1 \\
& (S y, S d)=\frac{1}{6}(0+0+0+1+0+0+0+0+0+0+1+0+0+0+1+0)=\frac{3}{6}=0,5
\end{aligned}
$$


$(S y, E s)=\frac{1}{6}(1+0+0+0+0+0+1+0+0+0+0+0+0+0+0+0)=\frac{2}{6}=0,3333$
$(S y, D m)=\frac{1}{6}(1+1+0+1+0+1+0+0+1+0+1+0+1+0+1+0)=\frac{8}{6}=1,33333$
$(S y, A k)=\frac{1}{6}(1+1+0+1+0+0+1+1+0+0+0+0+0+0+0+0)=\frac{5}{6}=0,83333$

Tabel 5. Nilai Preferensi untuk Kriteria Kr1

\begin{tabular}{|c|c|c|c|c|c|}
\hline $\begin{array}{l}\text { Kr1 (Sy, Sj) } \\
d=K r 1(S y)-K r 1(S j) \\
d=5-5 \\
d \leq 0 \\
\text { maka } H(d)=0\end{array}$ & $\begin{array}{l}\text { Kr1 (Sj,Sy) } \\
\text { d=Kr1(Sj)-Kr1(Sy) } \\
d=5-5 \\
d \leq 0 \\
\text { maka } H(d)=0\end{array}$ & $\begin{array}{l}\text { Kr1 (Ed,Sy) } \\
d=K r 1(S d)-K r 1(S y) \\
d=5-5 \\
d \leq 0 \\
\text { maka } H(d)=0\end{array}$ & $\begin{array}{l}\text { Kr1 (Es,Sy) } \\
d=K r 1(E s)-K r 1(S y) \\
d=3-5 \\
d \leq 0 \\
\text { maka } H(d)=0\end{array}$ & $\begin{array}{l}\text { Kr1 (Dm,Sy) } \\
d=C 1(D m)-1(\text { Sy }) \\
d=3-5 \\
d \leq 0 \\
\text { maka } H(d)=0\end{array}$ & $\begin{array}{l}\text { Kr1 (Ak,Sy) } \\
d=K r 1(A k)-K r 1(S y) \\
d=4-5 \\
d \leq 0 \\
\text { maka } H(d)=0\end{array}$ \\
\hline $\begin{array}{l}\text { Kr1 (Sy, Sd) } \\
d=K r 1(S y)-K r 1(S d) \\
d=5-5 \\
d \leq 0 \\
\text { maka } H(d)=0\end{array}$ & $\begin{array}{l}\text { Kr1 (Sj,Sd) } \\
d=K r 1(S j)-K r 1(S d) \\
d=5-5 \\
d \leq 0 \\
\text { maka } H(d)=0\end{array}$ & $\begin{array}{l}\text { Kr1 (Sd,Sj) } \\
d=K r 1(S d)-K r 1(S j) \\
d=5-5 \\
d \leq 0 \\
\text { maka } H(d)=0\end{array}$ & $\begin{array}{l}\text { Kr1 (Es,Sj) } \\
d=K r 1(E s)-K r 1(S j) \\
d=3-5 \\
d \leq 0 \\
\text { maka } H(d)=0\end{array}$ & $\begin{array}{l}\text { Kr1 }(D m, S j) \\
d=K r 1(D m)-K r 1(S j) \\
d=3-5 \\
d \leq 0 \\
\text { maka } H(d)=0\end{array}$ & $\begin{array}{l}\text { Kr1 (Ak,Sj) } \\
d=K r 1(A k)-K r 1(S j) \\
d=4-5 \\
d \leq 0 \\
\text { maka } H(d)=0\end{array}$ \\
\hline $\begin{array}{l}\text { Kr1 (Sy, Es) } \\
d=K r 1(\text { Sy)-Kr1(Es) } \\
d=5-3 \\
d>0 \\
\text { maka } H(d)=1\end{array}$ & $\begin{array}{l}\text { Kr1 (Sj,Es) } \\
d=K r 1(S j)-K r 1(E s) \\
d=5-3 \\
d>0 \\
\text { maka } H(d)=1\end{array}$ & $\begin{array}{l}\mathrm{Kr} 1(\mathrm{Sd}, \mathrm{Es}) \\
\mathrm{d}=\mathrm{Kr} 1(\mathrm{Sd})-\mathrm{Kr} 1(\mathrm{Es}) \\
\mathrm{d}=5-3 \\
\mathrm{~d}>0 \\
\text { maka } \mathrm{H}(\mathrm{d})=1\end{array}$ & $\begin{array}{l}\text { Kr1 (Es,Sd) } \\
d=K r 1(E s)-K r 1(S d) \\
d=3-5 \\
d \leq 0 \\
\text { maka } H(d)=0\end{array}$ & $\begin{array}{l}\text { Kr1 (Dm,Sd) } \\
d=K r 1(D m)-K r 1(S d) \\
d=3-5 \\
d \leq 0 \\
\text { maka } H(d)=0\end{array}$ & $\begin{array}{l}\text { Kr1 (Ak,Sd) } \\
d=K r 1(A k)-K r 1(S d) \\
d=4-5 \\
d \leq 0 \\
\text { maka } H(d)=0\end{array}$ \\
\hline $\begin{array}{l}\text { Kr1 (Sy, Dm) } \\
d=K r 1(S y)-K r 1(D m) \\
d=5-3 \\
d>0 \\
\text { maka } H(d)=1\end{array}$ & $\begin{array}{l}\text { Kr1 }(\mathrm{Sj}, \mathrm{Dm}) \\
\mathrm{d}=\mathrm{Kr} 1(\mathrm{Sj})-\mathrm{Kr} 1(\mathrm{Dm}) \\
\mathrm{d}=5-3 \\
\mathrm{~d}>0 \\
\text { maka } \mathrm{H}(\mathrm{d})=1\end{array}$ & $\begin{array}{l}\text { Kr1 (Sd,Dm) } \\
d=K r 1(S d)-K r 1(D m) \\
d=5-3 \\
d>0 \\
\text { maka } H(d)=1\end{array}$ & $\begin{array}{l}\text { Kr1 (Es,Dm) } \\
d=K r 1(E s)-K r 1(D m) \\
d=3-3 \\
d \leq 0 \\
\text { maka } H(d)=0\end{array}$ & $\begin{array}{l}\text { Kr1 (Dm,Es) } \\
d=K r 1(D m)-K r 1(E s) \\
d=3-3 \\
d \leq 0 \\
\text { maka } H(d)=0\end{array}$ & $\begin{array}{l}\text { Kr1 (Ak,Dm) } \\
d=K r 1(A k)-K r 1(D m) \\
d=4-3 \\
d>0 \\
\text { maka } H(d)=1\end{array}$ \\
\hline $\begin{array}{l}\text { Kr1 (Sy, Ak) } \\
d=K r 1(\text { Sy)-Kr1(Ak) } \\
d=5-4 \\
d>0 \\
\text { maka } H(d)=1\end{array}$ & $\begin{array}{l}\text { Kr1 (Sj,Ak) } \\
d=K r 1(S j)-K r 1(A k) \\
d=5-4 \\
d>0 \\
\text { maka } H(d)=1\end{array}$ & $\begin{array}{l}\text { Kr1 (Sd,Ak) } \\
d=K r 1(S d)-K r 1(A k) \\
d=5-4 \\
d>0 \\
\text { maka H(d)=1 }\end{array}$ & $\begin{array}{l}\text { Kr1 (Dm,Ak) } \\
d=K r 1(D m)-K r 1(A k) \\
d=3-4 \\
d \leq 0 \\
\text { maka } H(d)=0\end{array}$ & $\begin{array}{l}\text { Kr1 (Dm,Ak) } \\
d=K r 1(D m)-K r 1(A k) \\
d=3-4 \\
d \leq 0 \\
\text { maka } H(d)=0\end{array}$ & $\begin{array}{l}\text { Kr1 (Ak,Dm) } \\
\text { d=Kr1(Ak)-Kr1(Dm) } \\
d=4-3 \\
d>0 \\
\text { maka } H(d)=1\end{array}$ \\
\hline
\end{tabular}

Tabel 6. Hasil nilai preferensi dari setiap kriteria (Kr1 s/d Kr16)

\begin{tabular}{|c|c|c|c|c|c|c|c|c|c|c|c|c|c|c|c|c|}
\hline \multirow{2}{*}{ Nilai } & \multicolumn{16}{|c|}{ Kriteria } \\
\hline & $\mathrm{Kr} 1$ & $\mathrm{Kr}_{2}$ & $\mathrm{Kr}_{3}$ & $\mathrm{Kr}_{4}$ & $\mathrm{Kr} 5$ & $\mathrm{Kr}_{6}$ & $\mathrm{Kr}_{7}$ & $\mathrm{Kr} 8$ & $\mathrm{Kr} 9$ & $\mathrm{Kr} 10$ & $\mathrm{Kr} 11$ & $\mathrm{Kr}_{12}$ & $\mathrm{Kr}_{13}$ & $\mathrm{Kr}_{14}$ & $\mathrm{Kr}_{15}$ & $\mathrm{Kr}_{16}$ \\
\hline $\mathrm{Sy}, \mathrm{Sj}$ & 0 & 1 & 0 & 1 & 0 & 0 & 0 & 0 & 1 & 0 & 1 & 0 & 1 & 0 & 1 & 0 \\
\hline Sy,Sd & 0 & 0 & 0 & 1 & 0 & 0 & 0 & 0 & 0 & 0 & 1 & 0 & 0 & 0 & 1 & 0 \\
\hline Sy, Es & 1 & 0 & 0 & 0 & 0 & 0 & 1 & 0 & 0 & 0 & 0 & 0 & 0 & 0 & 0 & 0 \\
\hline Sy,Dm & 1 & 1 & 0 & 1 & 0 & 1 & 0 & 0 & 1 & 0 & 1 & 0 & 1 & 0 & 1 & 0 \\
\hline $\mathrm{Sy}, \mathrm{Ak}$ & 1 & 1 & 0 & 1 & 0 & 0 & 1 & 1 & 0 & 0 & 0 & 0 & 0 & 0 & 0 & 0 \\
\hline Sj,Sy & 0 & 0 & 0 & 0 & 0 & 0 & 0 & 0 & 0 & 0 & 0 & 0 & 0 & 0 & 0 & 0 \\
\hline $\mathrm{Sj}, \mathrm{Sd}$ & 0 & 0 & 0 & 0 & 0 & 0 & 0 & 0 & 0 & 1 & 0 & 0 & 0 & 0 & 0 & 0 \\
\hline $\mathrm{Sj}, \mathrm{Es}$ & 1 & 0 & 0 & 0 & 0 & 0 & 1 & 0 & 0 & 0 & 0 & 0 & 0 & 0 & 0 & 0 \\
\hline $\mathrm{Sj}, \mathrm{Dm}$ & 1 & 1 & 0 & 1 & 0 & 1 & 0 & 0 & 1 & 0 & 1 & 0 & 1 & 0 & 1 & 0 \\
\hline $\mathrm{Sj}, \mathrm{Ak}$ & 1 & 0 & 0 & 0 & 0 & 0 & 1 & 1 & 0 & 0 & 0 & 0 & 0 & 0 & 0 & 0 \\
\hline Sd,Sy & 0 & 1 & 1 & 0 & 1 & 0 & 0 & 0 & 1 & 1 & 0 & 1 & 1 & 1 & 0 & 1 \\
\hline $\mathrm{Sd}, \mathrm{Sj}$ & 0 & 1 & 1 & 0 & 1 & 0 & 0 & 0 & 1 & 1 & 0 & 1 & 1 & 1 & 0 & 1 \\
\hline Sd,Es & 1 & 1 & 0 & 0 & 1 & 0 & 1 & 0 & 1 & 0 & 0 & 1 & 1 & 0 & 0 & 1 \\
\hline Sd,Dm & 1 & 1 & 0 & 1 & 1 & 1 & 0 & 0 & 1 & 0 & 1 & 1 & 1 & 0 & 1 & 1 \\
\hline $\mathrm{Sd}, \mathrm{Ak}$ & 1 & 1 & 0 & 0 & 0 & 0 & 1 & 1 & 1 & 1 & 0 & 0 & 0 & 1 & 0 & 0 \\
\hline Es,Sy & 0 & 0 & 1 & 0 & 1 & 1 & 0 & 0 & 0 & 1 & 0 & 1 & 0 & 1 & 0 & 1 \\
\hline $\mathrm{Es}, \mathrm{Sj}$ & 0 & 1 & 1 & 1 & 1 & 1 & 0 & 0 & 1 & 1 & 1 & 1 & 1 & 1 & 1 & 1 \\
\hline Es,Sd & 0 & 0 & 0 & 1 & 0 & 1 & 0 & 0 & 0 & 0 & 1 & 0 & 0 & 0 & 1 & 0 \\
\hline Es,Dm & 0 & 1 & 0 & 1 & 0 & 1 & 0 & 0 & 1 & 0 & 1 & 0 & 1 & 0 & 1 & 0 \\
\hline Es,Ak & 0 & 1 & 0 & 1 & 0 & 0 & 1 & 1 & 0 & 1 & 0 & 0 & 0 & 1 & 0 & 0 \\
\hline Dm,Sy & 0 & 0 & 1 & 0 & 1 & 0 & 0 & 0 & 0 & 1 & 0 & 1 & 0 & 1 & 0 & 1 \\
\hline $\mathrm{Dm}, \mathrm{Sj}$ & 0 & 0 & 1 & 0 & 1 & 0 & 0 & 0 & 0 & 1 & 0 & 1 & 0 & 1 & 0 & 1 \\
\hline $\mathrm{Dm}, \mathrm{Sd}$ & 0 & 0 & 0 & 0 & 0 & 0 & 0 & 0 & 0 & 0 & 0 & 0 & 0 & 0 & 0 & 0 \\
\hline Dm, Es & 0 & 0 & 0 & 0 & 0 & 0 & 1 & 0 & 0 & 0 & 0 & 0 & 0 & 0 & 0 & 0 \\
\hline $\mathrm{Dm}, \mathrm{Ak}$ & 0 & 0 & 0 & 0 & 0 & 0 & 1 & 1 & 0 & 1 & 0 & 0 & 0 & 1 & 0 & 0 \\
\hline Ak,Sy & 0 & 0 & 1 & 0 & 1 & 1 & 0 & 0 & 0 & 0 & 0 & 1 & 1 & 0 & 0 & 1 \\
\hline $\mathrm{Ak}, \mathrm{Sj}$ & 0 & 0 & 1 & 0 & 1 & 1 & 0 & 0 & 1 & 0 & 1 & 1 & 1 & 0 & 1 & 1 \\
\hline $\mathrm{Ak}, \mathrm{Sd}$ & 0 & 0 & 1 & 0 & 0 & 1 & 0 & 0 & 0 & 0 & 1 & 1 & 0 & 0 & 1 & 0 \\
\hline $\mathrm{Ak}, \mathrm{Es}$ & 1 & 0 & 1 & 0 & 1 & 1 & 0 & 0 & 0 & 0 & 0 & 1 & 1 & 0 & 0 & 1 \\
\hline $\mathrm{Ak}, \mathrm{Dm}$ & 1 & 1 & 1 & 1 & 1 & 1 & 0 & 0 & 1 & 0 & 1 & 1 & 1 & 0 & 1 & 1 \\
\hline
\end{tabular}


Hasil dari perhitungan Indeks Preferensi Multikriteria dapat dilihat pada Tabel 7.

Tabel 7. Indeks Preferensi Multikriteria

\begin{tabular}{cccccccc}
\hline & Sy & Sj & Sd & Es & Dm & Ak & $\sum$ \\
\hline Sy & & 1 & 0,5 & 0,3333 & 1,3333 & 0,8333 & 3,9999 \\
Sj & 0 & & 0 & 0,3333 & 1,3333 & 0,5 & 2,1666 \\
Sd & 1,6666 & 1,6666 & & 1,3333 & 1,8333 & 1,1666 & 7,6664 \\
Es & 1,1666 & 2,1666 & 0.6666 & & 1,1666 & 1 & 5,4998 \\
$\mathrm{Dm}$ & 1 & 1 & 0 & 1,1666 & & 0,6666 & 3,8332 \\
$\mathrm{Ak}$ & 1,1666 & 1,6666 & 0,8333 & 1,1666 & 2 & & 6,8331 \\
\hline$\sum$ & 4,9998 & 7,4998 & 1,3333 & 4,3331 & 7,6665 & 4,1665 & \\
\hline
\end{tabular}

Tahapan leaving flow dilakukan untuk menentukan urutan prioritas dengan menggunakan urutan parsial. Penghitungan nilai leaving flow menggunakan Persamaan 8 dengan hasil perhitungan sebagai berikut.

$S y=\frac{1}{(1-6)} \times 4,9999=\frac{1}{5} \times 4,9999=0,79998$
$S j=\frac{1}{(1-6)} \times 2,1666=\frac{1}{5} \times 2,1666=0,43332$
$S d=\frac{1}{(1-6)} \times 7,6664=\frac{1}{5} \times 7,6664=1,53328$
$E S=\frac{1}{(1-6)} \times 5,4998=\frac{1}{5} \times 5,4998=1,09996$
$D m=\frac{1}{(1-6)} \times 3,8332=\frac{1}{5} \times 3,8332=0,76664$
$A k=\frac{1}{(1-6)} \times 6,8331=\frac{1}{5} \times 6,8331=1,36662$

Tahapan entering flow adalah tahapan perhitungan berdasarkan Persamaan 9.

Sy $=\frac{1}{(1-6)} \times 4,9998=\frac{1}{5} \times 4,9998=0,8333$

$S j=\frac{1}{(1-6)} \times 7,4998=\frac{1}{5} \times 7,4998=1,2499$

$S d=\frac{1}{(1-6)} \times 1,3333=\frac{1}{5} \times 1,3333=0,2222$

$E s=\frac{1}{(1-6)} \times 4,3331=\frac{1}{5} \times 4,3331=0,7221$

$D m=\frac{1}{(1-6)} \times 7,6665=\frac{1}{5} \times 7,6665=1,2777$

$A k=\frac{1}{(1-6)} \times 4,1665=\frac{1}{5} \times 4,1665=0,6944$

Tahapan selanjutnya, menghitung nilai net flow. Pada perhitungan ini, hasil akhir dalam penyelesaian masalah dengan hasil urutan yang lengkap berdasarkan Persamaan 10.

$S y=0,79998-0,83330=-0,03332$
$S j=0,43332-1,24996=-0,81665$
$S d=1,53328-0,22222=1,31106$
$E S=1,09996-0,72218=0,37777$
$D m=0,76664-1,27775=-0,51111$
$A k=1,36662-0,69441=0,67220$

Tabel 8.Hasil Perhitungan Promethee

\begin{tabular}{ccccc}
\hline Inisial Penyuluh & Leaving Flow & Entering Flow & Net Flow & Ranking \\
\hline Sy & 0,79998 & 0,83330 & $-0,03332$ & 4 \\
Sj & 0,43332 & 1,24996 & $-0,81665$ & 6 \\
Sd & 1,53328 & 0,22222 & 1,31106 & 1 \\
Es & 1,09996 & 0,72218 & 0,37777 & 3 \\
Dm & 0,76664 & 1,27775 & $-0,51111$ & 5 \\
Ak & 1,36662 & 0,69441 & 0,67220 & 2 \\
\hline
\end{tabular}


Pada hasil perhitungan net flow dapat dilihat kode penyuluh Sd mempunyai nilai net flow terbesar, yaitu 1,31106. Hasil perhitungan Promethee dapat dilihat pada Tabel 8.

Pada hasil perhitungan Promethee dapat dilihat bahwa yang memperoleh hasil nilai net flow terkecil adalah inisial penyuluh $\mathrm{Sj}$ dengan peringkat 6 net flow -081665. Berdasarkan perhitungan selisih antara leaving flow dan entering flow, maka dapat dilakukan pemeringkatan dengan nilai tertinggi sampai dengan terendah adalah dengan inisial penyuluh sebagai berikut: Sd, Ak, Es, Sy, Dm, dan Sj. Dari hasil perhitungan Promethee dapat disimpulkan bahwa kode penyuluh Sd merupakan penyuluh pertanian yang memiliki hasil evaluasi kinerja yang terbaik. Berdasarkan hasil nilai net flow, kode penyuluh Sd mendapatkan peringkat 1dengan nilai net flow 1,31106, dan kode penyuluh Sj dan Dm merupakan penyuluh pertanian yang membutuhkan rekomendasi pembinaan lebih lanjut oleh koordinator UPT BPP Sukaraja dalam melaksanakan tugas dan tanggung jawab sebagai seorang penyuluh. Kode penyuluh tersebut memiliki hasil evaluasi yang jelek, yaitu peringkat 5 dengan nilai net flow -0,81665 dan 6 dengan nilai net flow -0,51111. Berdasarkan pengujian yang dilakukan selama ini di UPT BPP melalui hitungan manual dengan menggunakan metode Promethee dapat disimpulkan bahwa kesesuaian yang diperoleh sebesar $70,32 \%$, sehingga metode ini dapat diterapkan dalam evaluasi kinerja penyuluh. Penelitian ini dapat membantu UPT BPP Sukaraja melakukan evaluasi kinerja penyuluh pertanian yang dilakukan setiap 3 bulan sekali. Penelitian ini juga dapat membantu tim evaluasi kinerja dalam menentukan penyuluh yang baik dengan melaksanakan tanggung jawab sebagai seorang penyuluh pertanian. Penerapan metode ini secara tepat dapat meminimalisasi kesalahan.

\section{Kesimpulan}

Hasil dari Promethee dalam mengevaluasi kinerja dapat disimpulkan bahwa menggunakan sampel yang sama dengan metode yang berbeda dari penelitian sebelumnya menghasilkan nilai alternatif yang sama dengan hasil yang baik. Faktor keberhasilan pada penelitian ini adalah jika jumlah nilai keseluruhan kriteria yang diperoleh dari hasil penilaian memiliki jumlah nilai yang tinggi dengan menerapkan metode Promethee dan metode sebelumnya, akan menghasilkan peringkat alternatif yang baik. Dalam penelitian ini, data penyuluh yang dilakukan penilai adalah 6 orang sehingga perhitungan Promethee dilakukan dengan manual. Jika sampel yang dilakukan dalam perhitungan lebih banyak, perhitungan secara manual dinilai tidak efektif. Untuk itu, penelitian harus dilakukan dengan mengembangkan sistem yang lebih akurat. Berdasarkan pengujian yang dilakukan, dapat disimpulkan bahwa metode Promethee dapat menghasilkan keputusan dengan pemeringkatan kinerja penyuluh. Selanjutnya, penelitian diharapkan dapat dikembangkan dengan metode lain yang ada pada decision support, sehingga dapat dibandingkan dengan hasil penelitian sebelumnya dan dapat dipilih metode yang efektif dalam evaluasi kinerja.

\section{Ucapan Terima Kasih}

Ucapan terima kasih kami sampaikan kepada Koordinator UPT BPP Sukaraja dan seluruh staf, serta Lembaga Penelitian dan Pengabdian kepada Masyarakat Universitas Dehasen Bengkulu.

\section{Referensi}

Adawiyah, R. (2015). Penerapan Metode Promethee Dalam Menentukan Dosen Terbaik. Seminar Nasional Informatika 2015 (pp. 631-635). Medan: Universitas Potensi Utama.

Apriliani, D., \& Somantri, O. (2019). Implementasi Metode Promethee Dalam Sistem Pendukung Keputusan Penilaian Raport Dosen. Jurnal Informatika: Jurnal Pengembangan IT (JPIT) , 4 (1), 38-42.

Ariansyah, S., Aknuranda, I., \& Rachmadi, A. (2013). Sistem Pendukung Keputusan evaluasi kinerja penyidik anggota Polri dengan menggunakan metode Promethee (Studi Kasus Direktorat Reserse Kriminal Umum Polda Jatim Surabaya). Repositori Jurnal Mahasiswa PTIIK UB , 2 (10).

Bahua, M. I. (2010). Faktor-Faktor yang Mempengaruhi Kinerja Penyuluh Pertanian dan Dampaknya pada Perilaku Petani Jagung Di Provinsi Gorontalo. Bogor: Institut Pertanian Bogor.

Brans, J.-P., \& Mareschal, B. (2016). PROMETHEE METHODS. In S. Greco, M. Ehrgott, \& J. R. Figueira, Multiple Criteria Decision Analysis: State of the Art Surveys (pp. 163-195). New York: Springer. 
Gunawan, \& Astuti, S. (2013). Sistem Pendukung Keputusan pemilihan gadget Android menggunakan metode Promethee. Techno.Com , 12 (2), 104-116.

Herman, M. (2014, 7 13). A Multi-Criteria Decision Making Approach to Problem Solving. Brussel, Belgia.

Hutahaean, M., Rosnita, R., \& Yulida, R. (2016). Analisis kinerja penyuluh pertanian dalam memberdayakan dan memandirikan petani karet di Kecamatan Gunung Toar Kabupaten Kuantan Singingi. Jurnal Online Mahasiswa (JOM) Bidang Pertanian , 3 (2), 1-7.

Pertanian, K. (2013, September 24). Peraturan Menteri Pertanian Nomor 91/Permentan/OT.140/9/2013 tentang Pedoman Evaluasi Kinerja Penyuluh Pertanian. Jakarta, DKI Jakarta, Indonesia. Retrieved from http://perundangan.pertanian.go.id/admin/file/Permentan\%20912013\%20Evaluasi\%20Kinerja\%20Penyuluh\%20Pertanian.pdf

Sapar, \& Butami, L. (2017). Faktor-faktor yang mempengaruhi kinerja penyuluh pertanian dalam peningkatan produktivitas kakao di kota Palopo. Jurnal Ekonomi Pembangunan , 3 (1), 35-42.

Sari, R. E., \& Saleh, A. (2014). Penilaian kinerja dosen dengan menggunakan metode AHP (Studi kasus: STMIK Potensi Utama Medan). Seminar Nasional Informatika 2014 (pp. 108-114). Medan: Universitas Potensi Utama.

Suranti, D., \& Sari, H. L. (2018). Penerapan Metode MPE dalam Penilaian Kinerja Penyuluh Pertanian UPT BPP Sukaraja. Jurnal Media Infotama , 14 (2), 74-78.

Vinodh, S., \& Girubha, R. J. (2012). PROMETHEE based sustainable concept selection. Applied Mathematical Modelling , 36 (11), 5301-5308.

Wibowo, R. M., Permanasari, A. E., \& Hidayah, I. (2015). Sistem Pendukung Keputusan pemilihan marketing officer berprestasi dengan metode Promethee (Studi Kasus: BRI Kantor Cabang Katamso Yogyakarta). Seminar Nasional Teknologi Informasi dan Multimedia 2015 (pp. 2.2-151 2.2156). Yogyakarta: STMIK AMIKOM.

Yu, X., Xu, Z., \& YingMa. (2013). Prioritized Multi-Criteria Decision Making based on the Idea of PROMETHEE. Procedia Computer Science , 17 (2013), 449-456.

Zuraidah, E., \& Marlinda, L. (2018). System Penunjang Keputusan Pemilihan Tempat Wisata Lombok Menggunakan Metode Preference Rangking Organization For Enrichman Evaluation (Promethee). Jurnal Teknik Komputer , 4 (1), 223-226. 